\title{
Marital satisfaction of visually impaired couples
}

\author{
Nur Zahra Suaidi ${ }^{1}$, Jamayah Saili ${ }^{* 2}$ \\ ${ }^{12}$ Universiti Malaysia Sarawak, Malaysia \\ *)Corresponding author, ఏe-mail: sjamayah@unimas.my
}

\begin{abstract}
Despite the relatively high degree of research among disabilities in Malaysia, there remains lack of research on issues and challenges faced by visually impaired couples. Visually impaired couples may experience different set of challenges and seek different needs for a satisfying married life as compared to typical couples. The research was conducted qualitatively by interviewing four visually impaired couples. The analysis of in-depth interviews with the couples yields three main themes which are the challenges, the coping strategies, and the future hopes of the visually impaired couples.
\end{abstract}

Keywords: visually impaired, marriage, satisfaction, disability, support

How to Cite: Suaidi, N., \& Saili, J. (2019). Marital satisfaction of visually impaired couples. COUNS-EDU: The International Journal of Counseling and Education, 4(3), 114-120. DOI: https://doi.org/10.23916/0020190421230

\section{Introduction}

Marriage is the fundamental basis of a personal association between a man and woman and a biological relationship for mating and reproduction; it unites partners socially and economically, which is relatively consistent over time and accords each member with certain agreed-upon rights. However, when long-term sickness or known as disability encounters in a couple's life, it can be stressful for the couple and this permanent disability could lead to sudden effect on the marital relationship. In the case of marital relationships, when a spouse's functional becomes limited, it will also affect the role of healthy partners to support disabilities of the partner. Hence, visual disability will curtail an individual's lifestyle (Schwartz \&Scott, 2012). There are three objectives for this research, which are to explore the challenges faced by spouses with visual impairment, the coping strategies and to obtain their future hopes. Hence, the significance of this study is to help couples with vision impairment to know their rights and raise their motivation and strength with visually impaired spouses. In addition, it can help them to have an open communication with their spouses and resolve the conflict which will lead to the success of marriage and decrease the level of divorce rate.

Marital satisfaction is one of the common concepts used for assessing happiness and stability in a marriage. One latest study conducted by Zeinab et al. (2016) stated that the factor comes from a multidimensional concept. Correlated to this, it is also one of the most important indicators of life satisfaction and family performance. Marital satisfaction is a process that comes into existence in the life of couples because it requires compliance with tastes, knowledge of personality attributes, establishing rules of behaviour, and formation of relationship patterns because marital relationship is the primary source of social support for most couples and acts as a protective factor against both psychological and physiological affliction; marital satisfaction affects physical and mental health, life satisfaction, success in work, and social communication (Akbari, 2009). As quoted from Alyson Aliano (2018), through Christian perspectives, marriage is a formal union; it is a social and legal contract between two individuals that unite 
their lives legally, economically, and emotionally. It is a contractual marriage by which they have legal obligations to each other until they decide to divorce. It is also added from another definitions, according to Merriam-Webster web (2012), marriage is the state of being united to a person of the opposite sex as husband or wife in a consensual and contractual relationship recognized by the law; the state of being united to a person of the same sex in a relationship like that of a traditional marriage [same-sex marriage], and the mutual relation of married persons that lead to the institution whereby individuals are joined in a marriage.

In addition, through the concept of Islam, Ibn 'Uthaimin ('Uthaymin) took an even more comprehensive view of the institution of marriage in his definition of it as follows, "It is a mutual contract between a man and a woman whose goal is for each to enjoy the other, become a pious family, and a sound society."

Marital satisfaction is a mental state that reflects the perceived benefits and costs of marriage to a person. The more costs a marriage partner inflicts on a person, the less satisfied one generally is with the marriage and with the marriage partner. Similarly, the greater the perceived benefits are, the more satisfied one is with the marriage and with the marriage partner. Unfortunately, for the disabled couples in fact, the disabled person is the one whose physical or mental health has been damaged temporarily or permanently, and who has lost his/her ability to perform personal and daily chores and social activities and as a result, he/she cannot continue living without help or special support and care. In other words, disability, due to severe and on-going problems which cause limitations and many psychological and social pressures for the individual and his/her family, has several consequences (Kathleen, 2012). Undoubtedly, the disabled person's spouse is the closest to the patient, having the greatest emotional, cognitive, verbal, and nonverbal relationship with the patient and this would distract their marital satisfaction of the marriage because of their partner.

\section{Methods}

This research was conducted by using qualitative approach. The design was to expose the unique furtherance of the case. Besides that, qualitative research enables the information to be collected in detail so that wider view of the research could be explored. This research focused on marital satisfaction of visually impaired couples and such method is helpful to obtain data and understand deeply in detail (Kathleen, 2012). The participants of this research study are from the Sarawak Society for the Blind (SSB) and four couples mainly involved in the interview session with the researcher. In the current study, the researcher used semi-structured interviews and the interview protocol was prepared. In contrast, qualitative research interview goes in depth and uses researcher's standards of quality (Brinkmann, 2001). Semi-structured interviews involve the questions to be predetermined, but the order as well as the wording can be modified, and questions can be omitted or added during the interview (Robson, 2002). The interviews were conducted in the researcher's language proficiency that can be in English, Malay, or local dialects such as Sarawak Malay dialect. The interview conversation were transcribed after the interview session had been done. Thematic analysis was utilized to analyze the data (Braun \& Clarke, 2016). According to Emily (2012), thematic analyses move beyond counting explicit words or phrases and focus on identifying and describing both implicit and explicit ideas within the data that are themes and it is applied to represent the linked raw data as summary markers for later analysis. 


\section{Results and Discussion}

Demographic Information

\begin{tabular}{|c|c|c|c|c|}
\hline Participant & F.C Couple & F.A Couple & M.R Couple & SA.TJ Couple \\
\hline Current Age & $\begin{array}{l}40 \text { (Husband) } \\
42 \text { (Wife) }\end{array}$ & $\begin{array}{l}51 \text { (Husband) } \\
31 \text { (Wife) }\end{array}$ & $\begin{array}{l}76 \text { (Husband) } \\
46 \text { (Wife) }\end{array}$ & $\begin{array}{l}54 \text { (Husband) } \\
52 \text { (Wife) }\end{array}$ \\
\hline Ethnic & Iban & Malay & Iban & Malay \\
\hline Place of Origin & Sarawak & Sarawak & Sarawak & Sarawak \\
\hline Occupation & $\begin{array}{l}\text { Both are } \\
\text { working at } \\
\text { Reflexology } \\
\text { Massage for } \\
\text { the Blind } \\
\text { People. }\end{array}$ & $\begin{array}{l}\text { Both are working } \\
\text { at Reflexology } \\
\text { Massage for the } \\
\text { Blind People. }\end{array}$ & $\begin{array}{l}\text { Wife, } \\
\text { Reflexology } \\
\text { Massage } \\
\text { Blind Centre. } \\
\text { Husband } \\
\text { (non- } \\
\text { worker) }\end{array}$ & $\begin{array}{l}\text { Husband, } \\
\text { Professional } \\
\text { Massage } \\
\text { Centre Wife, } \\
\text { A Secondary } \\
\text { School } \\
\text { Teacher. }\end{array}$ \\
\hline $\begin{array}{l}\text { Number of } \\
\text { Child/Age of } \\
\text { Child }\end{array}$ & $\begin{array}{l}1 \text { Child- } 12 \\
\text { Years Old }\end{array}$ & $\begin{array}{l}3 \text { Children }-12,10 \\
\text { and } 4 \text { years old }\end{array}$ & $\begin{array}{l}1 \text { Child }-19 \\
\text { Years Old }\end{array}$ & $\begin{array}{l}1 \text { child } \\
\text { (Deceased) }\end{array}$ \\
\hline Type of Disability & $\begin{array}{l}\text { Both are Blind } \\
\text { OKU }\end{array}$ & $\begin{array}{l}\text { Both are Blind } \\
\text { OKU }\end{array}$ & $\begin{array}{l}\text { Husband } \\
\text { (Deaf + Blurry } \\
\text { Vision) } \\
\text { Wife(Blind } \\
\text { OKU) }\end{array}$ & $\begin{array}{l}\text { Both are Blind } \\
\text { OKU }\end{array}$ \\
\hline
\end{tabular}

Four couples were interviewed in this research. They are originally from Sarawak and most of them are majority ethnics of local Sarawak which are Iban and Malay. Besides that, all the couples have children, and only one couple has a deceased child. Most of them work as massage therapists for blind people and have a certificate to work as professional massage therapists for blind people, while only one person works as a teacher. Apart from that, their overall types of disability are blind except for M.R Couple, where the husband is deaf and has blurry vision.

There are three main themes that emerged from the data, which were to explore the challenges faced by couples with visual impairments, to explore the coping strategies by visually impaired couples, and their future hopes on their marital relationship in many aspects. 


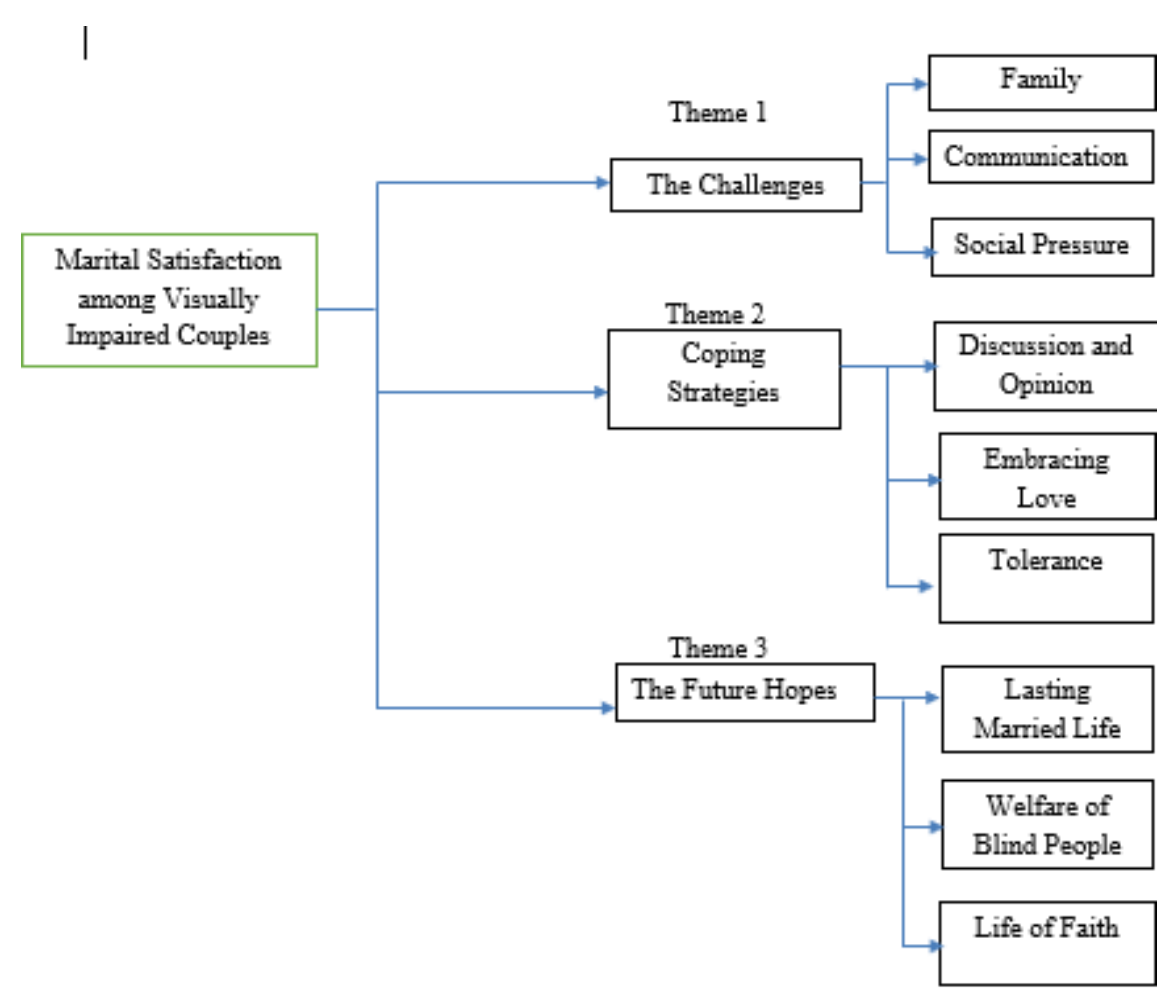

Figure 1 : Structural Overview of Three Major Themes and Sub-Themes

Figure1 shows the structural overview for each theme. In this study, each major theme has three-sub themes. Theme 1 discussed the challenges faced by the spouses with visual impairments; it includes the family origin, communication, and social life. Next, Theme 2 discussed the coping strategies by the visually impaired couples. Lastly, Theme 3 discussed the future hopes of their marital relationships which are lasting marriage, welfare of OKU blind people, and motivation in life.

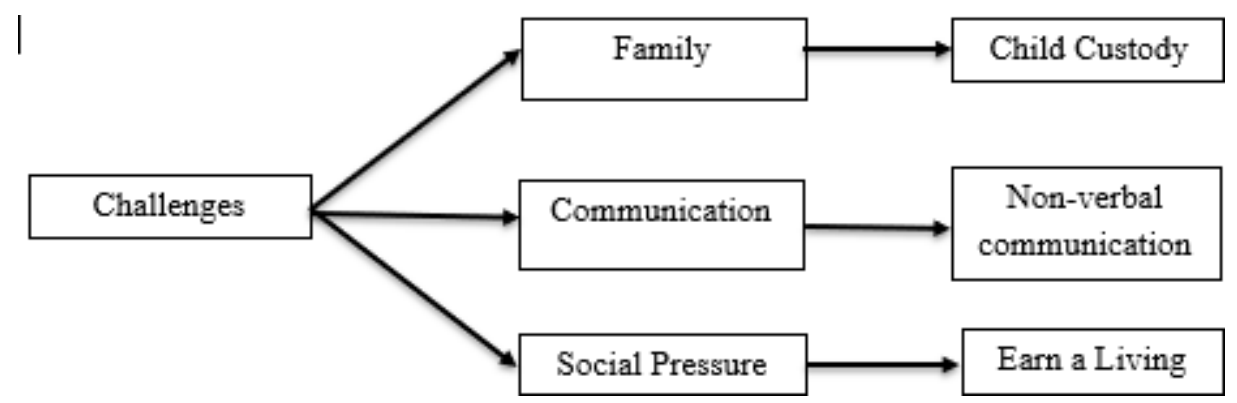

Figure 2 : The Challenges

The challenges of the visually impaired couples include the family that is child custody, communication that is non- verbal cues, and social pressure that constitutes to earn a living for their survival.

Firstly, the challenge comes from the family, which is child custody. This happens because of family's interference and their family does not put a high trust on them to raise their child. This statement was supported by the National Council on Disability (2012), who stated that parents with disabilities that are engaged in the custody or visitation in the family law will regularly encounter discrimination.

Next is communication, which is non-verbal cue. For the visually impaired couples, non-verbal cues are important because they help the couples to have a better communication. This is supported by a study 
conducted by Humprey (2015), which stated that non-verbal compliments also bring closer or move apart from expressing emotions. Hence, the problem encounters when the partners change the habitual practice of relying on non-verbal cues as a part of the message and this makes they lose the cues of communication.

Lastly, the challenge is social pressure. This is more to unemployment among the participant and correlates to how they earn a living. One of the studies conducted by Ling \& Khoo (2013) stated that there are biases and discriminations in hiring the visually impaired people because they have a negative view and prevalent misconceptions in the job market. This stereotyping often happens when it comes to hiring disabled people.

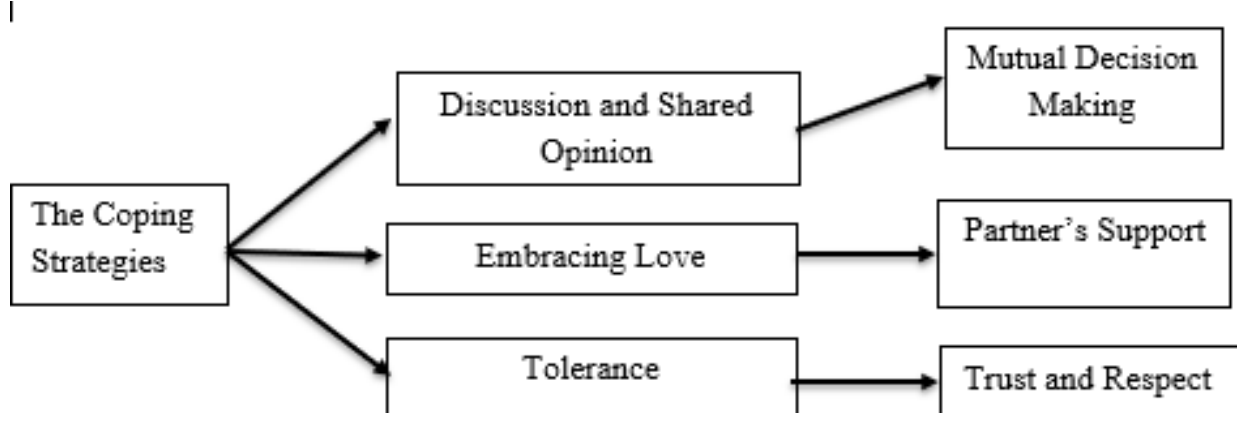

Figure 3 : The Coping Strategies

Based on the findings, the coping strategies firstly discussed is through discussion and shared opinion that comes out with mutual decision making, while the next sub-theme is embracing love through partner support and lastly followed by tolerance that comes with trust and respect. One literature review that can support mutual decision making as one

of the coping strategies is the study conducted by Avivi et al. (2009), which indicated that stability and quality depend on the partners' sharing of meaningful goals. Another study conducted by Mackey \& Bernard (2010) stated that one of the lasting married adaptations is through mutual decision together and it can also avoid conflicts in the marital relationship.

Next is partner support. This finding was supported by a study conducted by Vanover (2016), which stated that the important factor in marital success is partner's support and the consequence of divorces is the loss of a key source of support.

Lastly, the strategy is trust and respect. One study conducted by Moone (2012) revealed that trust is vital to healthy personalities and satisfying relationships and trust has been described as a belief, expectancy, and a feeling such as "an individual's belief in, and willingness to act on the basis of, the words, actions, and decisions of another". Hence, vulnerability can be particularly great in close, intimate relationships where there is significant investment of self and dependence upon the other (Johnson, Makinen, \& Millikin, 2001).

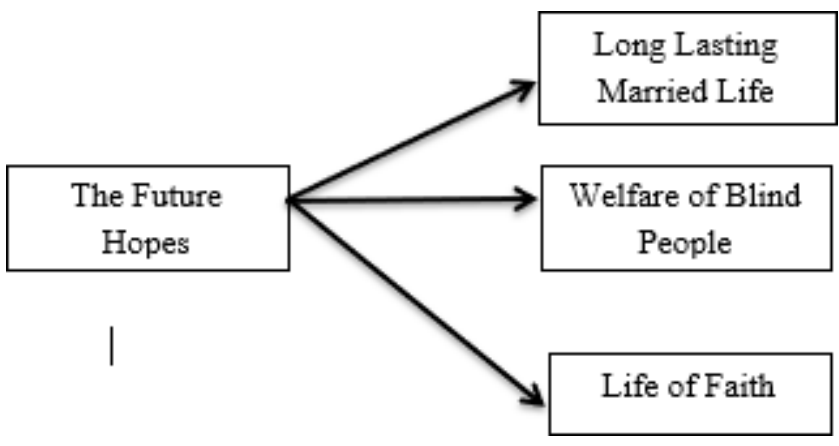

Figure 4 : The Future Hope 
According to the Malaysian Government Department of Social Services (2014), in order to provide for the future with high need for supports, they must reflect on hopes and dreams for the future of the persons especially the people with disabilities. Creating visions, hopes, and dreams are plans that they are willing to fulfil for their dreams and do best with their ability. All the future hopes and need, mentioned by the visually impaired participants are similar because they are convinced and congruent to each other. All participants want a long-lasting married life and no one in this world want to experience divorce. With regards to the welfare of blind people, they are hopeful that they can manage to build a home and rescue other visual handicapped people. Finally, they expressed, the hope is life of faith. This is meaningful because they have high enthusiasm in life and the belief that God creates something not only without purpose but it comes with wonderful reasons in life.

\section{Conclusion}

In conclusion, the three main findings in this research are the challenges, the coping strategies, and the future hopes of visually impaired couples. The participants had encountered some challenges such as from their family, communication, and their social pressure too. They also came out with coping strategies through discussion and shared opinion, embracing love, and having tolerance in their daily life.

\section{References}

Akbari. (2009). Mental health, life satisfaction, success in work, and social communication. Marital Satisfaction. doi:10.1109/inmic.2009.5383155

Alyson, A. (2018). The Definition of Marriage. Retrieved from https://www.thespruce.com/definition-ofmarriage- 2303011

Avivi, Rosika, \& Evina. (2009). Linking Relationship Quality to perceived Mutuality in Marriage. Retrieved

from http://www.bing.com/cr?IG=21F227AB6DBD4F5A931C6F12B113A5BB\&CID=215D6076479E 609E010F6C7046

636124\&rd=1\&h=uIS8BXhAGO7Xel3mKTQ-iFt2sRTy4whkHZxs-

fQPckQ\&v=1\&r=http://www.psy.miami.edu/faculty/ccarver/abstracts/09_avivi_JSCP.pdf \&p=D evEx.LB.1,5068.1

Brinkmann. (2001). InterViews: Learning the Craft of Qualitative Research Interviewing: Amazon.de: Steinar Kvale, Svend Brinkmann: Fremdsprachige Bücher. Retrieved from https://www.amazon.de/InterViews-Learning- Qualitative-Research-Interviewing/dp/0761925422

Braun, \& Clarke. (2006, August 12). Thematic analysis in Qualitative Study. Retrieved from http://www.bing.com/cr?IG=A7887DCA527D4F1AB50A6B7A493C3E4B\&CID=17F544F9D08 A6EC23E3948FFD1776F1B\&rd=1\&h=xKmR9qXsP9_n87FjqLr89ItVLkJ9ekUFOSVRUEHCeeQ $\& v=1 \& r=h t t p: / /$ eprints.uwe.ac.uk/11735/2/thematic_analysis_revised_final.pdf\&p=DevEx.LB.1 , 5519.1

Emily. (2012, May 14). Applied Thematic Analysis. Retrieved from http://us.sagepub.com/enus/nam/applied- thematic-analysis/book233379

Humprey. (2015). Top 5: Marital Issues. Retrieved from http://www.csg.org/pubs/capitolideas/2015_jan_feb/top5_federalism.aspx

Kathleen. (2012). Vision impairment and blindness. Retrieved from http://www.who.int/en/newsroom/fact- sheets/detail/blindness-and-visual-impairment

Ling, \& Khoo. (2013). Emloyment of Visual Handicapped. Retrieved from http://journals.sagepub.com/doi/abs/10.1177/1049909113500136

National Health Interview Survey on Disability. (2012, August 15). Retrieved from https://www.cdc.gov/nchs/nhis/nhis_disability.htm

Murray, Mckay, Nieuwoudt, Nyman, Gosney, \& Victor. (2010). Needs Of Visual Impairment Couples. Retrieved from https://issuu.com/wescom/docs/bulletin_daily_20110717

Martin, A. (2014, August 07). Definition of Legal Blindness. Retrieved from https://www.avvo.com/attorneys/60604- il-alexis-martin-4277209.html

Moone. (2012). Et-Moone B2B Relationships Questionnaire. PsycTESTS Dataset. doi:10.1037/t48145000

Robson,B. (2002, September 28). Collecting data by in-depthinterviewing. Retrieved from http://www.leeds.ac.uk/educol/documents/000001172.htm 
Sampson. (2004). A Guide to Using Qualitative Research Methodology. Retrieved from https://www.bing.com/cr?IG=64C7337060C2498889AF56675A7B52AD\&CID=2E8658677EB56 C1A000254617F486DF5\&rd=1\&h=GEhh2AsxTOegIV1agdh-z42Qna66 PDhLyQBcj28cc4\&v=1\&r=https://cloudfront.ualberta.ca/-/media/science/research-andteaching/teaching/qualitative-research-methodology.pdf\&p=DevEx.LB.1,5834.1

Schwartz, M. and Scott, B. (2012). Marriages and families. Boston: Prentice Hall.

Smith.(1999). Mixing Interview and Pilot Study : Qualitative. Retrieved from http://www.bing.com/cr?IG=2D1BFAF24ABA4EF5B4731213BA76DF80\&CID=0658073831D4 60EF31B30B3E30

2961CB\&rd=1\&h=00rTZ3ccXa1SeQaLgDb54n8WOGO8ukywzdlAdo0ysE\&v=1\&r=http://www.pareonline.net/getvn.asp?v=15\&n=1\&p=DevEx.LB. $1,5875.1$

Vanover, K. E. (2016). Factors in marital success and satisfaction. Behavioural Pharmacology,10(1). doi:10.1097/00008877-199908001-00244

Zeinab T., Zahra B.M, Alireza N.N, Nikzad I, \& Maryam E. (2016). Marotal satisfaction through the lens of Iranian women: A qualitative study. Pan African Medical Journal, 25, doi:10.11604/pamj.2016.25.208.9769208 